\title{
Giblews, Jews and Genizah Views
}

\author{
Stefan C. Reif \\ St John's College, Cambridge
}

S olomon Schechter's relationships with his work, his environment and the $\mathcal{N}$ people around him were rarely anything but intense. ${ }^{1}$ From his earliest days in mid-nineteenth century Rumania, through his years as a leading scholar of rabbinic literature in Central and Western Europe, until the final period of his life in the U.S.A., he responded enthusiastically to the challenges of fresh faces and novel contexts. It was perhaps this powerful interaction with 'the other' that led Cambridge University Librarian, Francis Jenkinson, to say of him: "nothing could give a sufficient notion of him to a person who never saw him.' ${ }^{2}$ Schechter left the impact of his dynamic personality wherever he had made close contact but also took away with him the influences and lessons derived from whatever he had liked and admired. A teacher in the Eastern Galician province of the Austro-Hungarian Empire inspired the early (but by no means permanent) rejection of his native Hasidism; scholars in Vienna and Berlin enthused him with philological and literary-critical approaches to Rabbinic literature; and what he found on the American continent drove him to champion the causes of centrist Judaism, adult education and religious Zionism.

Such an assessment is also undoubtedly true of the period that he spent in England, at first in London from 1882 until 1890, and subsequently in Cambridge from 1890 until his departure for New York in 1902. He mastered the English language and its use as a debating tool, identified closely with liberal and scholastic values, and developed friendships that influenced not only those who cultivated them but also the wider circles in which they operated. The close company in which he best expressed himself in London, 'the Wanderers', was dominated by the writer Israel Zangwill, the critic Joseph Jacobs, and Schechter himself. Other participants were the journalist Asher Myers, the scholar Israel Abrahams, and the historian Lucien Wolf, and Schechter also developed a close relationship with the Zionist pioneers, Herbert and Susie Bentwich. ${ }^{3}$

\footnotetext{
${ }^{1}$ For all the biographical information on Schechter here cited, see Norman Bentwich, Solomon Schechter: A Biography (Philadelphia, 1938); Alexander Marx, 'Solomon Schechter', in his Essays in Jewish Biography (Philadelphia, 1947); Cyrus Adler, 'Solomon Schechter: A Biographical Sketch', American Jewish Year Book 5677 (1916), 24-67; Jacob Sussmann, 'Schechter the Scholar' (in Hebrew), Jewish Studies 38 (1998), 213-30; Mel Scult, 'Schechter's Seminary', in The Making of an Institution of Jewish Higher Learning, the first volume of the two-volume study Tradition Renewed: A History of the Jewish Theological Seminary, ed. Jack Wertheimer (New York, 1997), 43-102; and Stefan C. Reif, 'Solomon Schechter', Oxford Dictionary of National Biography (Oxford, 2004).

2 Schechter Archive, Jewish Theological Seminary of America, New York: letter from Francis Jenkinson to Margaret Gibson, 21 January 1916. I am grateful to the Library of the Seminary for kindly making this material available to me.

${ }^{3}$ Bentwich, Schechter (see n. 1 above), 59-70; Stefan C. Reif, 'Jenkinson and Schechter at
} 
As far as the Cambridge world of the 1890s is concerned, the Bible scholar William Robertson Smith had supported his appointment as university lecturer and his acceptance as a member of Christ's College. ${ }^{4}$ In addition, many leading members of the university, such as Charles Taylor, Master of St John's College, and Francis Jenkinson, Robertson Smith's successor as University Librarian, enjoyed his wit, valued his remarkable mind and admired his prodigious learning. ${ }^{5}$ Nevertheless, it was with the pioneering anthropologist, James Frazer, a Fellow of Trinity for most of his professional life who never obtained a tenured teaching appointment at Cambridge, that he enjoyed a particular closeness. ${ }^{6}$ Indeed, a number of his main friendships were with those outside the established academic society, such as the literary raconteur and librarian, Eirikr Magnusson, and two of the leading Cambridge women of their day, Mary Kingsley, who was destined to perish as a serving nurse in colonial Africa, and the historian at Newnham College, Alice Gardner. ${ }^{7}$

It is not therefore surprising that Margaret Dunlop Gibson and Agnes Smith Lewis, pillars of the Presbyterian community in Cambridge and beyond, were among the close friends of Solomon and Mathilde Schechter. These two wealthy and scholarly women, though having received a sound education in religion, literature and languages, nevertheless qualified for marginalisation in the circles of conventional Cambridge academe by virtue of their nationality, their gender and their religious non-conformism. The local scholastic establishment could never bring itself to regard them as anything but eccentric amateurs attempting to impose themselves on a predominantly male academic environment and turned a blind eye to the fact that they received honours and recognition from other distinguished institutions of learning. Inevitably, the Giblews as they came to be affectionately nicknamed, made many of their warmest friendships among less conventional and more liberal dons in the city. ${ }^{8}$

There were other aspects of their earlier activities that made them likely candidates for a close relationship with the Schechters when the latter were resident in Cambridge. By the time that they were co-operating with Solomon Schechter on their famous visits to Cairo in 1896 and 1897 (of which

Cambridge: An Expanded and Updated Assessment', Transactions of the Jewish Historical Society of England XXXII (1992), 287-88; Margery Bentwich, Lilian Ruth Friedlander: A Biography (London, 1957), 10.

${ }^{4}$ Stefan C. Reif, 'William Robertson Smith in Relation to Hebraists and Jews at Christ's College Cambridge', in William Robertson Smith: Essays in Reassessment, ed. W. Johnstone (Sheffield, 1995), 210-24.

${ }^{5}$ Stefan C. Reif, A Jewish Archive from Old Cairo: The History of Cambridge University's Genizah Collection (Richmond, Surrey, 2000), 54-63.

${ }^{6}$ R. Ackerman, J. G. Frazer: His Life and Work (Cambridge, 1987), 182-83; Bentwich, Schechter (see n. 1 above), 87-89.

7 Bentwich, Schechter (see n. 1 above), 83-115; 'Mathilde Schechter's Memoirs', Schechter Archive (see n. 2 above), 101.21; J. A. Venn, Alumni Cantabrigienses, part II: From 1752 to 1900, vol. iv (Cambridge, 1951), 290; Who Was Who, part II: 1916-1928 (London, 19925), 302; Dea Birkett, Mary Kingsley: Imperial Adventuress (Basingstoke, 1992).

8 For a delightful biography which has provided much of the general information cited here, see A. Whigham Price, The Ladies of Castlebrae (Gloucester, 1985); see also the MS sources cited in $\mathrm{n} .15$ below. 
more anon), they had made admirable, educational use of a huge fortuneequivalent in today's values to at least $£ 50 \mathrm{~m}$ - fortuitously and unexpectedly inherited by their father from an American cousin and bequeathed to them by him in 1866. They had studied not only the Classical languages but also Hebrew, Arabic and Syriac. During courageous journeys in the Eastern Mediterranean, they had discovered and purchased rare items in various Semitic languages that were destined to have a major impact on scholarship and had themselves edited and described texts of considerable importance to the early history of Christian literature. ${ }^{9}$ At St Catherine's Convent in Sinai they retrieved a precious Syriac manuscript of the Gospels that was being recycled as a butter-dish and they had written popular accounts of these and other adventures in that part of the world.

Margaret and Agnes were well acquainted with many of the Semitists of their day, including D. S. Margoliouth, Laudian Professor of Arabic in Oxford, and R. H. Kennett, subsequently Regius Professor of Hebrew in Cambridge, ${ }^{10}$ and had shared the vicissitudes and successes of their forays in the Near East, not always without considerable tensions, with their fellow travellers, James Rendel Harris, Robert Bensly and Francis Burkitt, the latter two accompanied by their wives. ${ }^{11}$ Rendell Harris was a distinguished Quaker scholar of early Christian documents and University Lecturer in Palaeography. Bensly had brought fresh Hebrew, Arabic and Syriac expertise into the University Library as early as 1864 . Educated in Bonn and Halle, as well as at Cambridge, he taught Hebrew at Gonville and Caius College from 1864 to 1876, served on the Old Testament Revision Committee and was elected Lord Almoner Professor of Arabic at Cambridge in 1887. Burkitt was at an early stage of his career and inclined to be less generous and saintly than he is reputed to have become in his more mature years when he became University Lecturer in Palaeography and later Norrisian Professor of Divinity and a renowned expert in the study and publication of difficult Greek and Semitic texts. He did assist the Giblews with their preparatory studies but also engaged in some academic wrestling with them in the matters of the ascription and publication of their precious discoveries. ${ }^{12}$

Fiercely Presbyterian though the twin Scottish savants undoubtedly were, their various accounts of how their lives had been touched by other religions and cultures in general and by matters Jewish in particular, clearly demon-

9 An appendix in Price, Ladies (see n. 8 above), 236-40, provides a detailed list of their published volumes.

10 There is a detailed obituary of Margoliouth by G. Murray in Proceedings of the British Academy 36 (London, 1940), 389-97. For Kennett, see Dictionary of National Biography, Supplement 1931-40 (London, 1949), 505-506, and Who Was Who, part III: 1929-1940 (London, $\left.1967^{2}\right), 474-76$.

11 On Harris, see Who Was Who, part IV: 1941-1950 (London, 19805), 505-506; on Bensly, see Dictionary of National Biography, Supplement I (London, 1901), 171; on Burkitt, see Proceedings of the British Academy 22 (1936), 445-84, and Dictionary of National Biography, Supplement 1931-40 (London, 1949), 124-25.

12 Price, Ladies (see n. 8 above), 132-61 and 185-87, and the correspondence between the Giblews and Rendell Harris to be found in the Gibson-Lewis Archive WGL 5 at Westminster College, Cambridge. 
strate that it was not only in the roles played by their gender that they were ahead of their time. Among the British travellers, scholars and colonialists of their period, some undoubtedly took a dim view of alternative lifestyles while others demonstrated a surprising degree of understanding and tolerance. There were also those whose attitudes represented an amalgam of the two elements. The biblical anthropologist at Cambridge, William Robertson Smith, for instance, may have been theologically antagonistic to rabbinic Judaism but this did not prevent him from coming to the aid of a rabbinic Jew being unfairly treated in a railway carriage. ${ }^{13}$ A. H. Sayce, the Oxford Semitist, thought of some Jews in stereotypical fashion while commending the individual attributes of others. ${ }^{14}$ What emerges from the published and unpublished reminiscences of the Giblews is clear evidence of an intense interest in humanity and an open-mindedness about its varying customs and commitments. Their visits to the Near East, especially to the Holy Land and Jerusalem, provided them with ample opportunity of recording their responses to whom and what they saw.

Although the Muslim, Jewish and non-Protestant residents of these countries found the notion of independent, scholarly women more than a trifle strange, the fact that these two visitors could read and speak their languages and make sensible comments about their cultures encouraged a meaningful level of communication. The funds that Margaret and Agnes had at their disposal also probably played a part in smoothing the way for them and they were particularly conscious of this in their dealings with Ottoman Turkish officials. They made no derogatory remarks about the Ramadan fasting but did express relief that the Prophet of Islam 'never came to Europe'. ${ }^{15}$ Similarly, they reported the ease of Islamic divorce and remarriage, noting that there was 'nothing wrong in a Moslem doing so' but forbearing to 'admire the system'. ${ }^{16}$ The local flora and fauna attracted their attention and they were especially excited by standing in places where they believed that biblical characters had stood many centuries earlier, sometimes using the opportunity to illuminate passages in the Old and New Testaments by reference to their practical experiences. ${ }^{17}$ Archaeology was a favourite interest and they took every opportunity of informing themselves about the latest excavations and findings by courtesy of those, such as Dr Frederick Bliss, who were then busily

13 Reif, 'William Robertson Smith' (see n. 4 above), 223.

14 A. H. Sayce, Reminiscences (London, 1923), 52-53, on Adolf Neubauer and his abandonment of 'the requirements of Jewish orthodoxy'; 92, on a Hungarian Jew 'difficult to train to the ways of civilised Christendom'; 191, on Shapiro as 'a typical Rabbi of the old school, credulous and uncritical beyond conception'; 325, on the Giblews as 'two learned ladies'.

15 Gibson-Lewis Archive at Westminster College, Cambridge, WGL 6/2, containing two manuscript essays by Mrs Gibson, one on a camel journey from Cairo to Jerusalem and another on the visit to Jerusalem itself, both in 1896. I shall refer to the former as WGL 6/2 (A) and the latter as WGL 6/2 (B). These two essays formed the basis of part of A. S. Lewis, In the Shadow of Sinai (Cambridge, 1898) but contained comments that were omitted from the published version. I am grateful to the College and its staff for their kindness in making this material available to me. The reference here is to WGL 6/2 (A), 5 .

16 Letter from Mrs Lewis in Suez to Mrs Schechter in Cambridge, 7 February, 1897, Schechter Archive (see n. 2 above)

17 WGL 6/2 (A), 3-5; WGL 6/2 (B), 4. 
engaged in this activity. They were thrilled to see the remnants of the ancient walls of Second Temple Jerusalem and to opt for an identification of the site of the Crucifixion as the green hill just outside the Damascus Gate and not the Church of the Holy Sepulchre. ${ }^{18}$ Though fascinated by what remained of the ancient world, they also took pleasure in seeing the arrival of modernity in the shape of steam-ships and railway lines and felt that the British presence in Egypt had brought more to that country than the Ottomans had to the Syrian areas of influence, a development that had led some of the local population to believe that an extension of Queen Victoria's Empire into the latter territories would not be unwelcome. ${ }^{19}$ They carried with them their cameras and tirelessly sought permission from religious dignitaries (more often than not with success) to commit hundreds of folios of precious Semitic manuscripts to film. ${ }^{20}$

Although expressly declaring their preference for their own simpler forms of worship, they attended such ceremonies as the feet-washing done on Maundy Thursday by the Latin Patriarch and the sacred fire on Easter Saturday, presided over by his Greek counterpart, noting the gorgeous apparel of the prelates and the sumptuously embroidered vestments of the churches. ${ }^{21}$ At the same time, they came to appreciate that

the members of the various Oriental churches, Greek, Roman, Syrian, Armenian, and Copt have a strong mutual antipathy to each other, besides thinking that they do God service by hating all Jews and Muhammadans, a feeling which is heartily reciprocated, so that a little spark is sufficient to light so much tinder and produce a fatal conflagration. ${ }^{22}$

The successful activities of the Protestant missionaries from the United Kingdom and the U.S.A. won their approval, the waning power of the Greek Church was noted, and the view expressed that more would move in their religious direction if they were not anxious about losing their livelihoods as a result. ${ }^{23}$ They generally commenced relationships by thinking well of their fellow humans, whatever their orientation, but sometimes suffered disappointment, as in the case of some militant Muslims of Gaza who shouted abuse at what they regarded as intrusive Christian heretics and attacked their escort with stones. As Mrs Gibson put it, when contrasting the physical attractiveness of the environment with the behaviour of the residents, 'Its minarets and palm-trees make a lovely combination. But, while "every prospect pleases",

\footnotetext{
18 Bliss, son of the President of the American College in Beirut, had previously worked with Flinders Petrie in Egypt and subsequently published Excavations at Jerusalem 1894-1897 (London, 1898) and The Development of Palestine Excavation (London, 1906); see C. M. Watson, Palestine Exploration Fund: Fifty Years' Work in the Holy Land: A Record and a Summary 18651915 (London, 1915). The Giblews' interest in his work is noted in WGL 6/2 (B), 4-7, 17-18. See also S. Gibson, Jerusalem in Original Photographs 1850-1920: Photographs from the Archives of the Palestine Exploration Fund (London, 2003), index, 201.

19 WGL 6/2 (B), 2; WGL 6/2 (A), 14; WGL 6/2 (A), 7; WGL 6/2 (B), 22.

20 WGL $6 / 2$ (B), 11; WGL 6/2 (B), 7-8.

21 WGL 6/2 (B), 9-10.

22 WGL $6 / 2$ (B), 14-15.

23 WGL 6/2 (B), 21-22.
} 
man, alas, is vile.' ${ }^{24}$

When convinced that the religious faith of others was simplistic or misguided, they refrained from judgement, polemic or challenge, merely allowing themselves on occasion a wry smile, as, for instance, when they told the story of the Greek woman from the Island of Chios who made a pilgrimage to Jerusalem. When shown the reputed site of Calvary,

she fell on her knees, and poured out her heart, as nearly as possible in the following words: O Jesus! O Lord! Why didst Thou come to this stony land? Why didst Thou not come to Chios? We have fine lemon-trees, and fine orangetrees, and we have splendid water. Why didst Thou not come to us? We would have crucified Thee! ${ }^{25}$

Jerusalem, of course, tugged at their theological heart-strings, with its 'charm ... antiquity ... and relics of a yet remoter past'. They took note of the large and growing Jewish population and of the expansion into the suburbs of the new city. The simplicity of the synagogues appealed to them and they saw in the old Jewish faces subjects 'well worthy of an artist's study'. ${ }^{26}$ The model of ancient Jerusalem prepared by Conrad Schick caught their imagination, technically capable as it was of being simply updated in the light of new discoveries, and they brought home to Cambridge a model of the Jewish tabernacle of the Mosaic period which had been made in Jerusalem according to their specifications. ${ }^{27}$ Although they looked forward to the future cleansing, both physical and spiritual, of the holy city ${ }^{28}$ they were, unlike some of their contemporaries, not unhappy with how it looked in its contemporary setting and development. Mrs Gibson generously felt that 'no happier site could have been chosen for the railway station' and expanded on this impression:

It stands about half a mile from the S.W. corner of the city and in no way interferes with its sacred associations. During my stay I heard a lady say that she was disappointed in Jerusalem. What did she expect to see? The Temple in all its glory? For a city that was utterly destroyed and levelled with the dust 1,900 years ago, Jerusalem puts on a brave appearance. She is not like Damascus, where the dark, narrow, squalid streets common to all Oriental cities almost completely hide all relics of former magnificence $\ldots{ }^{29}$

While waiting for the Greek Orthodox ceremony of the sacred fire, they heard some of the spectators chanting ditties in Arabic that contrasted the sad foolishness of the Jewish Passover festival with the joyous redemption brought to Christians and celebrated at Easter. They were unimpressed by such emotions describing them as a 'travesty of the Christian spirit' and a

${ }^{24}$ WGL 6/2 (A), 7-8; compare the published account in Lewis, Sinai (see n. 15 above), 147-48.

${ }^{25}$ WGL $6 / 2$ (B), 8, where the Greek original is also transcribed. For the later published version, see Lewis, Sinai (see n. 15 above), 168.

26 WGL 6/2 (B), 1, 19 and 17.

27 WGL 6/2 (B), 18; Price, Ladies (see n. 8 above), 171. On Schick, see Encyclopaedia Judaica 14, 957, and Gibson, Jerusalem (see n. 18 above), index, 203.

28 WGL 6/2 (B), 17.

29 WGL 6/2 (B), 2. 
'remnant of Baal-worship'. ${ }^{30}$ In Mrs Gibson's handwritten notes of the incident, she transliterates the Arabic of one of the songs and translates it as follows:

Your feast, O ye Jews,

Is for kangaroos;

Our feast is the feast of the Christ.

The Christ. He hath sought us,

With His blood He hath bought us,

This day we are glad,

And, O Jews, ye are sad.

When Mrs Lewis came to write her published account of the same topic, they had agreed a slightly different translation: ${ }^{31}$

Your feast, O ye Jews!

The apes they would choose.

Our feast is the feast of the Christ!

The Christ He hath sought us,

With His blood He hath bought us.

Right merry are we

When doleful ye be,

O Jews! ${ }^{32}$

It is unclear at which stage of their life the Giblews began to feel sympathetic towards the Jews and intrigued with their culture. Their Protestant minister and teacher in their hometown of Irvine in Ayrshire, William Robertson, was a man of broad culture, intense learning and wide experience, who had himself encountered Jews in his travels and he may already have inspired such attitudes. ${ }^{33}$ Certainly, by the time they made their first trip to the East in 1866, at the age of 23, they were ready to defend a more tolerant attitude than was common in that period. In a discussion with a young married woman from Bucharest, they were taken aback by the hatred she expressed for Turks and Jews. When it was pointed out to her that the Christian Saviour himself was a Jew, she responded, unperturbed, 'Ah! A Jew is a Jew wherever he is!' ${ }^{34}$

Given such lack of bigotry on the one hand and their common love of the Bible, the Holy Land, and the Hebrew language on the other, it is hardly surprising that Mrs Lewis and Mrs Gibson became friendly with the Schechters when Solomon and Mathilde arrived in Cambridge in 1890. Mrs Schechter soon became attached to a group of scholarly, independent and literary women in the University city who came to be at least as fascinated with her husband's intellectual brilliance and powerful personality as they had been impressed with her own cultural accomplishments. At first, the Giblews found

30 Lewis, Sinai (see n. 15 above), 167.

31 WGL 6/2 (B), 13.

32 Lewis, Sinai (see n. 15 above), 167, where the Arabic is now transcribed rather than transliterated. For a similar report by a Governor of Jerusalem during the British Mandate, see Ronald Storrs, Orientations (London, 1937), 413, a reference I owe to my friend and colleague, Professor William Horbury.

33 Price,Ladies (see n. 8 above), 20-24.

34 Agnes Smith, Eastern Pilgrims: The Travels of Three Ladies (London, 1870), 24-26. 


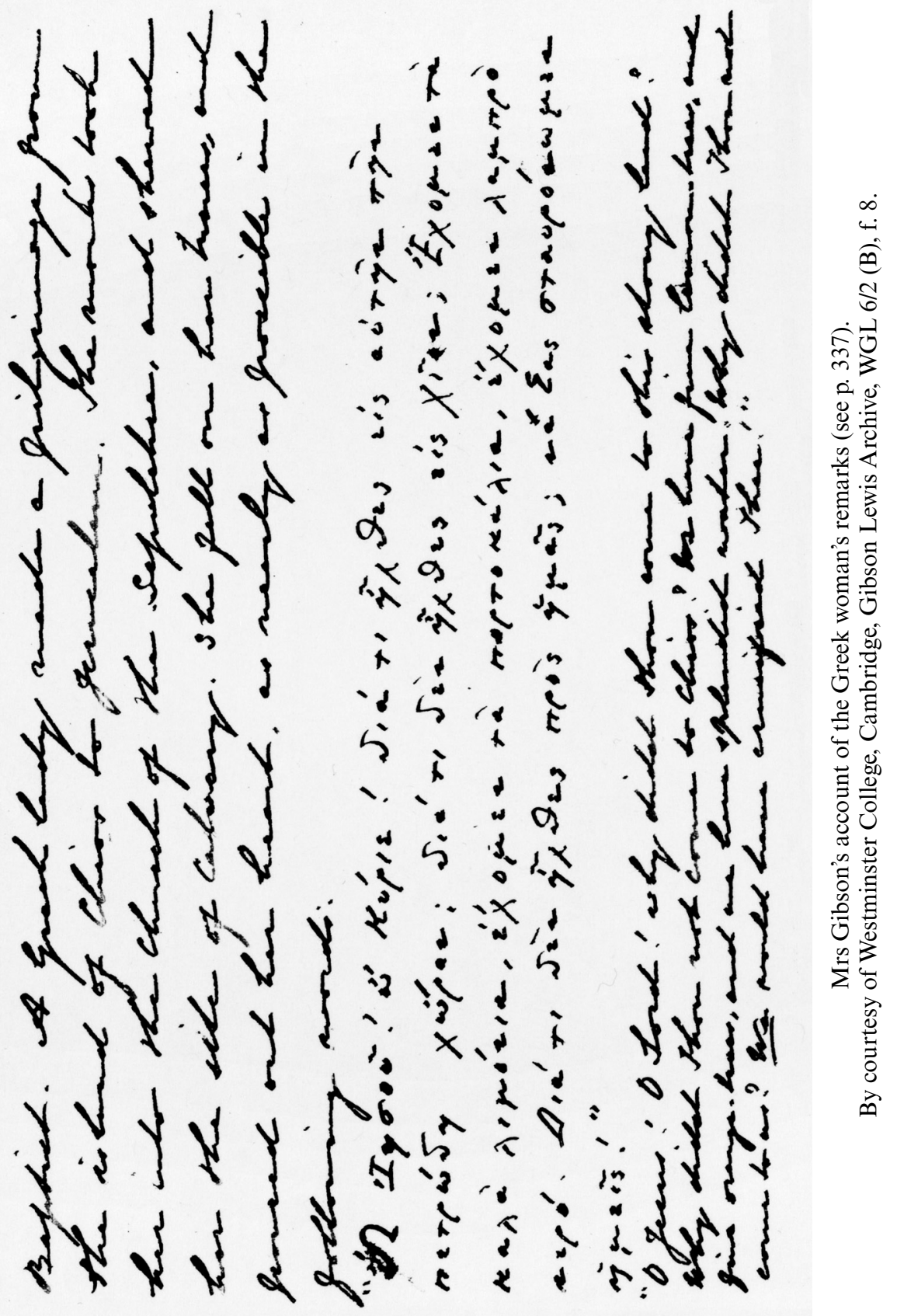


him something of a bookworm, perhaps a little shy of the imposing academic environment into which he had newly moved, but they were soon witnesses to the manner in which he blossomed. 'As friends multiplied,' Margaret later recalled, 'he grew more sociable, and endeared himself all round by his combination of amazing erudition, and a childlike simplicity.' ${ }^{35}$

What particularly impressed the sisters was that he too was no slouch when it came to demonstrating a combination of personal commitment and religious tolerance. He was keen to understand Christian beliefs and practices and took pride in the achievements of Jesus the Jew. What is more, he had a portrait of their own hero, John Knox, on his wall, and admitted to reading MacCrie's life of the Scottish Reformer as a solace whenever he was upset by the work of Biblical critics. His two Presbyterian friends regarded him as blessed with two of Knox's virtues, namely, fearlessness and fidelity to conscience. ${ }^{36}$ The Schechters for their part were thrilled to find Christians who were not only learned, sociable and philanthropic but also strict in religious observance. They noted that at 'Castlebrae', the twins' home in Chesterton Lane, New Year was celebrated, in Scottish Presbyterian fashion, with much more enthusiasm than Christmas Day, and that they walked to church on Sundays so that their coachman could enjoy his sabbath rest. When reminiscing about their Cambridge days some twenty years later, Mathilde recalled one occasion when Agnes and Margaret had suffered a severe attack of influenza. The first Sunday after their recovery was a very wet one but when the Schechters stood at their window and peered through the heavy rain, they were astonished to see their friends marching off to church just as usual. ${ }^{37}$ Although the Cambridge academic establishment somehow contrived not to include the Giblews among those who made a gift to the Schechters on their departure for New York in 1902, the two resourceful women were not to be outdone. They purchased a silver 'kiddush' goblet for him to use at the formal Friday evening supper at home and had it inscribed with a verse about wisdom from one of the Hebrew leaves of Ben Sira found by Solomon in the Genizah. ${ }^{38}$

When the Schechters came to Castlebrae late in 1895 to wish the Giblews well on the newest Near Eastern adventure on which they were about to embark, they were asked if there was anything special that could be brought back for them. ${ }^{39}$ As always, Schechter's passion was for hoary Hebrew manuscripts and it was suggested that his Scottish friends might locate and purchase some at the various antiquity shops that dealt in such treasures. Schechter had for a number of years entertained the notion that he might one day discover

\footnotetext{
35 'Dr. Solomon Schechter', an obituary by Margaret D. Gibson, The Week-Day, no. 10, 15 January 1916, 7, end of first paragraph.

36 In the final paragraph of the obituary cited in the previous note.

37 'Mathilde Schechter's Memoirs', Schechter Archive (see n. 2 above), 101.21, section dealing with Mrs Lewis and Mrs Gibson.

38 Letter from A. S. Lewis to Francis Jenkinson, 24 January 1903, in the Jenkinson correspondence at Cambridge University Library, 6463.5309.

39 'Mathilde Schechter's Memoirs', Schechter Archive (see n. 2 above), 101.21, section dealing with Mrs Lewis and Mrs Gibson.
} 
manuscript evidence to refute the view of scholars such as D. S. Margoliouth in Oxford that the rabbinic tradition had not transmitted or preserved any authentic Hebrew version of Ben Sira and that the Greek and the Syriac were the best witnesses to the original. ${ }^{40}$

Mrs Lewis and Mrs Gibson were true to their word about purchasing Hebrew manuscripts but, rather than obtaining for Schechter a few sample items, they in fact brought home early in May 1896 a haul of over 2,000 vellum and paper manuscripts from Jerusalem, the plain of Sharon and Cairo, which were to form the basis of what became the Lewis-Gibson Collection of Genizah fragments, bound up in fifteen sturdy volumes at Westminster College, Cambridge. ${ }^{41}$ They later recalled how these items had been exported from the Holy Land with some difficulty and that they had been destined to have a major impact on medieval Hebrew and Jewish scholarship:

We had some trouble about our boxes in the custom-house in Jaffa, especially with some Hebrew MSS they contained. Our dragoman protected those ancient leaves by assuring the official that they were necessary for us to say our prayers with. One of them, since our return to Cambridge, has been identified by $\mathrm{Mr}$ Schechter as a portion of Ecclesiasticus, unknown to the learned world since the days of Jerome. Is this not emblematical of the impressions we carry away from a journey in the East? We are not always conscious of their value at the time but they come up and prove helpful for years afterwards, nor is their worth to be measured by any scale at our command. ${ }^{42}$

They had not long returned to Castlebrae when they began to examine their Hebrew treasures. Although they could deal with the Hebrew Bible, they had to call on the services of Dr Schechter to help them identify items that were written in a form of Hebrew unfamiliar to them from their Old Testament studies. On 13 May, following a chance meeting between Mrs Lewis and Schechter outside King's College, Schechter came over to their home and examined the fragments, quickly identifying one as a vellum leaf of the Palestinian (=Jerusalem) Talmud, itself a significant find, given the paucity of manuscript sources for that work. It was, however, another 'scrap of paper' that attracted his closer attention and that he immediately wished to take with him for further study and for possible publication. Within a matter of hours he had communicated the result of his research to his women friends by way of telegram and letter, the text of the latter conveying the intensity of his excitement:

Dear Mrs Lewis, I think we have reason to congratulate ourselves. For the fragment I took with me represents a piece of the original Hebrew of Ecclesiasticus. It is the first time that such a thing was discovered. Please do not speak yet about the matter till tomorrow. I will come to you tomorrow about 11 p.m. [sic!]

40 Stefan C. Reif, 'The Discovery of the Ben Sira Fragments', in The Book of Ben Sira in Modern Research: Proceedings of the First International Ben Sira Conference 1996, ed. P. C. Beentjes (Berlin, 1997), 1-21.

41 B. Richler, Guide to Hebrew Manuscript Collections (Jerusalem, 1994), 35.

42 WGL 6/2 (B), 23-24; compare the published account in Lewis, Sinai (see n. 15 above), 16871. 
and talk over the matter with you how to make the matter known. In haste and great excitement, Yours sincerely, S. Schechter.

Although he expressly requested them to keep the matter confidential, he himself could not control his enthusiasm and spread the word among colleagues at the University Library. That same afternoon, they met at the Schechter home in Rock Road to discuss strategy. The result was that Mrs Lewis immediately wrote with the news to the Athenaeum and the Academy and Schechter prepared the text for publication in the July issue of the Expositor. What he had identified was a Hebrew text of parts of Ecclesiasticus 39-40 and he was convinced that it represented a reliable witness to the original language of the book. ${ }^{43}$ Now surely, he must have thought, the scholarly controversy had been settled in his favour. Little did he realise then that D. S. Margoliouth would not be convinced even when seriously challenged by T. Nöldeke and that the opposing view would not finally be refuted until discoveries by Yigael Yadin at Masada in $1964 .{ }^{44}$

Adolf Neubauer, an expert in Hebrew manuscript research, who had long been aware of the importance of Genizah collections in the Near East for Mediterranean scholarship, and Arthur Cowley, erudite Semitist, had, within five weeks of Mrs Lewis's letter appearing in the Athenaeum, located another nine leaves of the same manuscript of Ecclesiasticus at the Bodleian Library in Oxford. ${ }^{45}$ It is possible that they were already working on such a project but more probable that Mrs Lewis was right when she later made use of best British understatement and wrote that it was 'natural to think' that it was her letter of 13 May, published on 16 May, that had been 'of some assistance in guiding Messrs Neubauer and Cowley to this important result'. ${ }^{46}$

Inspired by the Lewis-Gibson discovery, as well as by his recollections of similar fragments on which the name of early Cairo, namely, 'Fustat', had appeared, and encouraged and financed by his friend and supporter, Charles Taylor, the Master of St John's College, Schechter set out for Cairo in December, 1896. Armed with the necessary letters of introduction, he quickly established cordial relations with what was effectively the British government of Egypt, and with its head, the Consul-General, Lord Cromer, and with the Chief Rabbi of Cairo, Aaron Raphael Ben-Shimion. Having been given full access to the Ben Ezra Synagogue and its Genizah treasures and permission to remove what he desired, he began to sort out the contents with a view to exporting the best items to Cambridge. The physical nature of the challenge

\footnotetext{
43 Lewis, Sinai (see n. 15 above), 172-80; 'Mathilde Schechter's Memoirs', Schechter Archive (see n. 2 above), 101.21, section dealing with the Ben Sira discovery; Price, Ladies (see n. 8 above), $197-99$.

44 Reif, 'Ben Sira Fragments' (see n. 40 above), 8.

45 For biographical details of Neubauer (1831-1907) and Cowley (1861-1931), see Dictionary of National Biography, Second Supplement (London, 1912), 5-7; Who Was Who 1897-1915 (London, 19886), 382; Dictionary of National Biography 1931-1940 (London, 1949), 194-95; Who Was Who 1929-1940 (London, 1941), 297. Their publication was The Original Hebrew of a Portion of Ecclesiasticus (XXXIX.15 to XLIX.11), together with the early Versions and an English Translation, followed by the Quotations from Ben Sira in Rabbinical Literature (Oxford, 1897).

${ }^{46}$ Lewis, Sinai (see n. 15 above), 175.
} 
should not be underestimated. He had to work in a dark and suffocatingly dusty atmosphere, suffering the close attentions of legions of insects and always aware that he might be damaging the very treasures that held out such hope for him. ${ }^{47}$

Meanwhile the exciting news had got back to Cambridge and the Giblews, who were about to set off for another visit to Sinai on 9 January, 1897, decided to visit their Rabbinic friend in Cairo on their way. Having consulted with Mathilde they were able to bring Solomon various useful items, including a 'respirator', a device obtained from the medical scientist, Dr Donald Macalister, that would make it easier for him to breathe in all the dust. They had also offered to take with them enough 'spools' to photograph the Genizah material but must soon have realized that the time and expense involved in dealing with what were then reckoned to be 100,000 fragments (and later numbered as 140,000$)$ put such a project beyond implementation. ${ }^{48}$ Schechter took them to the Ben Ezra synagogue to show them his place of work and source of discoveries. Mrs Gibson, and a former Girton College student called Miss Anna de $\mathrm{Wit}^{49}$ whom Schechter had apparently brought along too (perhaps in her capacity as journalist), climbed into the Genizah room and were appalled by the filthy conditions. The fragments had not only been crunched underfoot by all those who had jumped down into the attic room; they had also been assailed by generous quantities of whitewash, dust, sand and unidentified liquid. They wrote to Mathilde about their experiences, informing her that her husband had been working very hard, had found 'good things', was in good spirits, and ready to take a little holiday. ${ }^{50}$

Schechter had arranged for the fragments to be packed into sacks for transportation to Cambridge but in his absence a proportion of the items had found their way into the hands of local dealers in antiquities. The Scots visitors located them and purchased them, 'with Dr Schechter's full approbation', as they put it. Agnes and Maggie were somewhat averse to exporting heaps of dirt from Egypt to England and therefore took it upon themselves to clean

\footnotetext{
47 The official accounts were published by Schechter in The Times of 3 August 1897, and by the Giblews in Lewis, Sinai (see n. 15 above), 183-89. For more personal details, see the manuscript reports in his letter to Francis Jenkinson of 12 January 1897, in the Jenkinson correspondence at Cambridge University Library, 6463.3416; 'Mathilde Schechter's Memoirs', Schechter Archive (see n. 2 above), 101.21; and the letter from Mrs Lewis to Mrs Schechter of 21 January 1897, in that same archive. For some recent research on assessments of Lord Cromer by his contemporaries, see Paul Auchterlonie, 'A Turk of the West: Sir Edgar Vincent's Career in Egypt and the Ottoman Empire', British Journal of Middle Eastern Studies 27.1 (2000), 56-60.

48 Letters from Margaret Gibson to Mathilde Schechter of 5 January 1897, and from Agnes Lewis to Mathilde Schechter of 21 January 1897, preserved in the Schechter Archive (see n. 2 above).

49 Anna Augusta Henriette de Wit (1864-1939) studied modern languages at Girton College, Cambridge, 1889-1890, and was for many years correspondent and literary critic for Dutch and German papers. She was another woman ahead of her time in matters of education, culture and liberalism; see Girton College Register, vol. I: 1869-1946 (Cambridge, 1948), 56, and Girton Review 111 (Michaelmas Term, 1939), 43-44. I am grateful to Ms K. M. Perry, Girton College Archivist, for kindly providing this information.

50 Letter from Agnes Lewis to Mathilde Schechter of 21 January 1897, preserved in the Schechter Archive (see n. 2 above).
} 
up the manuscripts as best they could in their hotel room. They removed what accretions they could and, adopting a method that would not be highly approved by current conservation specialists, spread the precious texts on tables and trunks to dry in the sunlight. They were therefore able to return to Cambridge with a second batch of Genizah fragments, some of which they retained while others were consigned 'to Dr Schechter's care'. There were other westerners in their hotel at the time with whom the Cambridge party forged links and exchanged scholarly information and experiences. Mrs Lewis and Mrs Gibson were particularly helpful in introducing Dr Schechter to some local Christian and Muslim scholars with whom he was an outstanding social and intellectual success. They had disappointed him by not bringing him some light reading in the form of a novel but they made up for this by deciding to lend him their own copy of Robert Louis Stevenson's latest book Weir of Hermiston, even if they were concerned that he had enough to do in Cairo without being distracted by reading such literature. ${ }^{51}$

When Schechter returned to Cambridge in the late spring of 1897, he was already aware that what he had retrieved from the Ben Ezra synagogue would grant him scholarly immortality and that no one individual or generation would ever be able to quarry more than a small proportion of the collection's rich seams of new knowledge. He could nevertheless make a start on this massive challenge to scientific Jewish study and he consequently set about the systematic sorting of the fragments, assisted by a team of Cambridge scholars, each with a particular expertise. Mrs Lewis and Mrs Gibson dealt with the Syriac; Charles Taylor with post-biblical Hebraica and with palimpsests; Francis Burkitt with Greek items; Hartwig Hirschfeld with the Arabic; and Herman Leonard Pass with the Hebrew Bible. The University Librarian, Francis Jenkinson, was closely involved in all these research projects and kept the confidences of the researchers regarding their discoveries. ${ }^{52}$ Mrs Lewis and Mrs Gibson were soon describing some of their own Genizah finds and the latter presented a paper on the subject to the Cambridge Antiquarian Society on 14 November 1898. She dealt with the contents of two Judaeo-Arabic fragments, the first a deed from 1038 alluding to the recovery of a deposit in spite of the loss of the required receipt, and the second a document from 1149 representing a receipt for a variety of goods purchased. In addition, she discussed in some detail the paper used for these two items and the source from which it was manufactured. ${ }^{53}$

The Greek and Syriac items in the Genizah collections were not easily revealed nor simply deciphered and interpreted since they were lurking under later Hebrew texts in a number of palimpsests dating back as early as the fifth or sixth century. According to the testimony of the Giblews themselves, it was Schechter who first set aside the Syriac items and Burkitt who confirmed

\footnotetext{
51 Lewis, Sinai (see n. 15 above), 183-89; letters from Agnes Lewis to Mathilde Schechter of 21 January and 7 February 1897, preserved in the Schechter Archive (see n. 2 above).

52 Reif, Archive (see n. 5 above), 66-69 and 78-97.

53 Margaret Gibson, 'On Two Hebrew Documents of the 11th and 12th Centuries', Proceedings of the Cambridge Antiquarian Society, with Communications made to the Society X (1904), $1-5$.
} 
their identity and importance, but it was to the two redoubtable women who inspired Schechter's trip to Cairo that the task of editing them was entrusted in $1898 .{ }^{54}$ There is some evidence that Schechter was occasionally somewhat resentful that he had at all to enlist the support of any other scholars in the exciting work that he saw as ideally his exclusive prerogative. This perhaps even applied to his friends and collaborators, Mrs Lewis and Mrs Gibson. ${ }^{55}$ When the former happened to meet Mrs Schechter on the afternoon of 14 May 1899, and mentioned her plan to assist the good Rabbi with the cleaning of his fragments, she was informed that Dr Schechter was perfectly able to clean, arrange, and identify them by himself. She wrote next day to the University Librarian, Francis Jenkinson, declining to be further involved without specific invitation and concluding with the rather sharp remark that she admired and respected Schechter 'for things that are quite apart from neatness and tidiness'. ${ }^{56}$

Peace was made, perhaps through the good offices of Taylor and Jenkinson, and the Giblews soon got on with their editorial work, apparently even taking the fragments home with them where the reference literature was easily to hand and they had better sources of light. They consulted Jenkinson on matters of conservation and made use of what was referred to as a 'reagent' consisting of hydro-sulphuret of ammonia to improve the legibility of the texts. ${ }^{57}$ They prepared texts of thirty items from the Taylor-Schechter Collection and an additional four from their own Genizah collection. These texts count among the earliest set of Palestinian (and one Edessene) texts of the Syriac Bible, covering four books each in the Old and New Testaments. They subsequently included a few additional items, discovered somewhat later, in another volume. ${ }^{58}$ Quite how such material came to be used by rabbinic Jews as second-hand writing material, on which they could record their legal, homiletical and poetic compositions, is an intriguing question. Did Muslims capture Christian monasteries and sell the contents of their libraries to Jews as scrap? Were there Christian converts to Judaism who brought their religious texts with them into their new communities, to be used for the promotion of their adopted faith? Or was used vellum and paper simply available in the scribal market? The problem awaits its solution until further evidence is uncovered.

What is perfectly clear and already well attested is that the collection of Jewish manuscripts retrieved from the Genizah of the Ben Ezra Synagogue

54 A. S. Lewis and M. D. Gibson (eds), Palestinian Syriac Texts from Palimpsest Fragments in the Taylor-Schechter Collection (London, 1901), vii-x.

55 The evidence is presented and discussed in my Hebrew article, 'The Cambridge Genizah Story: Some Unfamiliar Aspects’, in Te 'uda 15, ed. M. A. Friedman (Tel Aviv, 1999), 413-28.

56 Letter from A. S. Lewis to Francis Jenkinson, 15 May 1899, in the Jenkinson correspondence at Cambridge University Library, 6463.3523. See also Ignaz Goldziher Tagebuch, ed. A. Scheiber (Leiden, 1978), p. 279 (a reference which I owe to Professor Geza Vermes).

57 Letters from A. S. Lewis to Francis Jenkinson, 8 July 1901, 28 April 1902, and 4 May 1902, in the Jenkinson correspondence at Cambridge University Library, 6463.4817, .5106 and .5112; Lewis and Gibson, Syriac Texts (see n. 54 above), ix.

58 A. S. Lewis, Apocrypha Syriaca. The Protevengelium Jacobi and Transitus Mariae ... with an Appendix of Palestinian Syriac Texts from the Taylor-Schechter Collection (London, 1902). 
in Fustat is a unique historical source. The 140,000 fragments presented by Taylor and Schechter to Cambridge University Library, as well as the 2,000 items brought back to Westminster College by the Giblews, and various other Genizah collections around the world, provide texts of inestimable significance for rewriting Jewish social, literary and religious history in the medieval Mediterranean area. ${ }^{59}$ Remarkably, the Genizah also provides insights into the ordinary life of the period and its numerous mundane items, relating to life, love, health, wealth and politics, testify to a society that was considerably more literate than its equivalent in Europe. ${ }^{60}$ If much of the credit for the retrieval of the Genizah manuscripts from Cairo and their scientific exploitation must go to Solomon Schechter, there is no doubt that Mrs Agnes Lewis and Mrs Margaret Gibson forged essential links in the chain of events that created such a significant scholarly development.

These two formidable Scotswomen made intrepid journeys in the Eastern Mediterranean and brought to England precious Semitic manuscripts. With a high degree of academic learning, they deciphered documents and edited texts, as well as describing and evaluating lifestyles that were wholly novel for them. They brought the Hebrew and Greek scriptures to life for many of their contemporaries by reporting in detail on the sights, the natural world and the excavations that they had seen in the Holy Land, documenting many of their experiences by way of hundreds of photographs. Though encouraging tolerance and mutual understanding between peoples, they were not afraid of expressing views on the unacceptable face of religious fundamentalism and emotion. They set impressive standards of piety as well as learning, encouraged women and men in the pursuit of scholarship, and were fastidious about arranging appropriate publicity for scientific discoveries. They generously offered their practical involvement in preparing manuscripts for publication and their specialised knowledge in the study of their contents.

Undoubtedly, they had their quirks of character, could be fairly tetchy and were at times regarded as figures of fun by those in their day who were uncomfortable with eccentric behaviour and passionate religiosity, especially on the part of women. What is, however, undeniable is that their learning, their expeditions, their work on manuscripts, their empathy with Jewish culture, and their struggles for those who did not belong to the establishment are characteristics that deserve to be recalled with admiration and with gratitude by those who are today, more than a century later, still reaping the benefits of what were undoubtedly pioneering efforts in so many different ways.

59 Reif, Archive (see n. 5 above), especially chs 5, 6 and 7.

${ }^{60}$ Reif, Archive (see n. 5 above), especially chs 8 and 9. 